\title{
Review
}

\section{Montaigne and the Tolerance of Politics}

\author{
Douglas I. Thompson \\ New York (NY) and Oxford: Oxford University Press, 2018, xiv + 229pp., \\ ISBN 978-0190679934
}

Contemporary Political Theory (2020) 19, S79-S81. https://doi.org/10.1057/s41296018-00291-y; published online 14 December 2018

In recent years, a series of studies on the work of Michel de Montaigne have focused on the writer's involvement in politics, and on his contribution to the understanding of political issues. Abandoning a well-established literary tradition that casts Montaigne as a contemplative scholar, retired from the affairs of the world, they have re-examined the Essays in light of the author's activities as mayor of Bordeaux and as mediator between the Catholic and Protestant camps during the religious wars that devastated France throughout his lifetime. Douglas I. Thompson's study Montaigne and the Tolerance of Politics embraces this new line of research, turning to the Essays to highlight a question as crucial today, as it was in Montaigne's own time: how to think (or, in our case, to rethink) a politics of tolerance in increasingly divided societies. Any reading of the Essays that adopts a contextual approach is bound to confront the ways in which the author's distinctive philosophical outlook was shaped by the dramatic conflicts of his times. Whether this makes the Essays a primarily political work, or one in which political issues gained space and importance at the expense of more speculative subjects - a question that Thompson raises in the Introduction - seems in the end a somewhat academic question, since it makes little difference to the relevance of the text.

After decades in which tolerance became a norm, contemporary democracies are confronted, once again, with the emergence of intolerant ideologies and intransigent political and religious groups. Faced with the resurgence of domestic conflict and terrorist threats, they discover that the modern ethos of tolerance and peaceful coexistence is powerless in the face of the demands of uncompromising minorities. The ineffectiveness of the liberal approach to tolerance and its incapacity to translate apparently impeccable principles into viable policies is the starting point of Thompson's analysis. He rightly identifies Montaigne's experience, such as it is expressed in his work or can be reconstructed from historical sources, as an especially valuable guide to the difficulties associated with the practice of toleration.

(c) 2018 Springer Nature Limited. 1470-8914 Contemporary Political Theory Vol. 19, S1, S79-S81 
For the secular and spiritual authorities of the mid-16th century France, the sudden explosion of religious conflict was probably even more baffling than any episodes of intolerance may prove for us today. French Catholics and Protestants were not divided by regional or ethnic identities, and they generally shared a culture. They did not represent conflicting economic interests, indeed they often belonged to the same social groups, even to the same families. What opposed obstructed them were exclusively their contrasting views of the Christian faith and of the role of the Church: thus the dynastic and territorial conflicts that emerged during the wars were originally the by-product of a genuine ideological struggle. Although the French monarchy and the parlements had plenty of experience in negotiating conflicts over all types of material issues, they found themselves powerless in the face of a demand that did not lend itself to any rational compromise: the claim to the monopoly over the revealed truth. For decades, violent persecution, as well as legislative attempts to accommodate diversity, proved equally ineffective as a means to secure peace.

In this context, Montaigne's search for solutions to promote reconciliation was eminently practical: it was based upon strategies of negotiation, dialogue, mutual recognition and exchange, rather than on the enforcement of legal norms; it advocated moderation as an exercise in self-control, rather than promoting abstract principles. Indeed, in the past, Montaigne's position has often been stigmatised by commentators as insufficiently 'modern' and progressive, since he did not regard tolerance as a virtue, and failed to define freedom of conscience as a fundamental right. In retrospect, his sceptical refusal to turn those notions into ethical or legal imperatives has emerged as the real point of strength of his analysis: such approach implies that tolerance is not a given value or an acquired right in any context, but a practice that needs to be constructed continuously by the joint efforts of different human groups. In particular, the Essays brought out the essential role of language and communication as the only viable alternative to violence in the building of social consensus.

The scope of Thompson's work is very ambitious, as it tries to weave together several different historical and philosophical dimensions: the investigation of the intricate background of Montaigne's personal experience, and the correspondent evolution of the project of the Essays; the understanding of tolerance of a wide range of 'liberal' philosophers, from J. S. Mill to Charles Taylor and John Rawls, from Judith Shklar and Bernard Williams to William Connolly (to mention only a few); finally, the author discusses a set of contemporary attempts to overcome civil conflicts along lines that recall Montaigne's own approach. The book takes as special examples the relations between Jews and Arabs in Palestine, and the activities of the Royal Commission on Aboriginal People in Canada. (It might have been interesting, incidentally, to add to this list the case of the Commission of Truth and Reconciliation in South Africa, which tried to promote the confrontation between victims and perpetrators of abuses during apartheid: Montaigne advocated 
a very similar strategy to overcome the wounds of the religious conflict, criticising the strategy of the French monarchy that imposed by law the complete 'forgetfulness' (oubliance) of any past traumatic experiences).

Inevitably, the wide spectrum of Thompson's study results in some unevenness in the way in which his arguments are developed and presented; in particular the transition from historical and textual reconstruction to philosophical analysis however well-researched - is not always obvious to the reader. But on the whole his book has the great merit to show how classical writers can offer valuable guidance to contemporary thinking; it is also a tribute to the lasting power and political potential of sceptical philosophy.

\section{References}

Connolly, W. (2005). Pluralism. Durham, NC: Duke University Press.

Desan, P. (2017). Montaigne: A Life. Princeton, NJ: Princeton University Press.

Fontana, B. (2008). Montaigne's Politics. Princeton, NJ: Princeton University Press.

Giocanti, S. (2001). Penser l'irrésolution: Montaigne, Pascal, La Mothe Le Vayer. Trois itineraires sceptiques, Paris, H. Champion.

Heyd, D. (Ed.). (1996). Toleration: An Elusive Virtue. Princeton, NJ: Princeton University Press.

Biancamaria Fontana

Centre Walras Pareto, Université de Lausanne, 1015 Lausanne, Switzerland biancamaria.fontana@unil.ch 